\title{
Notas sobre o abuso de forma e norma geral antielisão no direito tributário brasileiro
}

\author{
Notes on abuse of form and general anti-avoidance rule in Brazilian Tax Law
}

\author{
Carlos Renato Cunha* \\ Maurício Dalri Timm do Valle \\ Valterlei Aparecido da Costa***
}

\section{REFERÊNCIA}

CUNHA, Carlos Renato; VALLE, Maurício Dalri Timm do; COSTA, Valterlei Aparecido da. Notas sobre o abuso de forma e norma geral antielisão no direito tributário brasileiro. Revista da Faculdade de Direito da UFRGS, Porto Alegre, n. 44, p. 3-19, dez. 2020. DOI: https://doi.org/10.22456/0104-6594. 94812.

\section{RESUMO}

Artigo que visa a analisar a possibilidade e as consequências da declaração de fraude e/ou dissimulação em face dos Princípios da Legalidade, Segurança Jurídica e Capacidade Contributiva, assim como o tema da norma geral antielisão no Direito pátrio.

\section{PALAVRAS-CHAVE}

Direito Tributário. Evasão Fiscal. Fraude à Lei e Dissimulação. Legalidade. Segurança Jurídica. Capacidade Contributiva.

\section{ABSTRACT}

This article aims to analyze the possibility and consequences of the declaration of fraud and/or concealment regarding the Legality Principle, Legal Security and Contributory Capacity, as well as the theme of the general anti-avoidance rule in Brazilian law.

\section{KEYWORDS}

Tax Law. Tax evasion. Fraud in Law and Concealment. Legality. Legal security. Contributory Capacity.

\section{SUMÁRIO}

1. Introdução. 2. Evasão, Elisão, Elusão, Ilusão... 3. Legalidade, Liberdade e o Abuso de Formas no Direito Tributário. 4. A Lei Complementar 104/2001 e o parágrafo único do art. 116, do CTN. Conclusão. Referências. Dados da publicação.

\footnotetext{
* Doutorando e Mestre em Direito do Estado pela Universidade Federal do Paraná - UFPR. Especialista em Direito Tributário pelo Instituto Brasileiro de Estudos Tributários - IBET. Bacharel em Direito pela Universidade Estadual de Londrina - UEL. Professor Seminarista do IBET-Londrina. Professor de Direito Tributário e Financeiro da Graduação e da Pós-Graduação lato sensu na Pontifícia Universidade Católica do Paraná - PUCPR, campus Londrina. Procurador do Município de Londrina (PR). Advogado. E-mail: carlos@cko.adv.br. ** Bacharel, Mestre e Doutor em Direito do Estado pela UFPR. Professor do Programa de Pós-Graduação Stricto Sensu em Direito da Universidade Católica de Brasília - UCB - e de Direito Tributário da Graduação em Direito do Centro Universitário Curitiba - UniCuritiba *** Mestrando em Direito do Estado pela UFPR. Bacharel em Direito pela UFPR. Ex-Técnico de Finanças de Controle da Procuradoria da Fazenda Nacional. Advogado em Curitiba/PR.
} 


\section{INTRODUÇÃO}

O tema da liberdade negocial do contribuinte e suas consequências em relação às normas tributárias tem sido discutido intensamente pela doutrina nacional, no âmbito do tema do planejamento tributário e da dicotomia entre evasão e elisão tributárias.

Há situações, contudo, em que a linha entre a licitude e a ilicitude ficam tênues. A doutrina e a jurisprudência, judicial e administrativa, têm analisado o tema do abuso de formas ou da elisão tributária abusiva, com grande celeuma.

Diante desse quadro, pretende-se no presente artigo analisar brevemente as figuras da evasão ou elisão tributária no Direito Tributário Brasileiro, com os efeitos daí decorrentes. Para tanto, analisar-se-á os conceitos de evasão e elisão tributárias, assim como a figura próxima da elisão abusiva e a previsão do Parágrafo Único, do art. 116, do CTN, para, então, conceituar-se o fenômeno jurídico sob estudo e verificar a possibilidade, ou não, de o Fisco desconsiderar os negócios jurídicos de tal jaez, levando em considerando os efeitos que o norte dos Princípios da Legalidade, Segurança Jurídica e da Capacidade Contributiva trazem ao tema.

\section{EVASÃO, ELISÃO, ELUSÃO, ILUSÃO...}

A tensão existente entre os limites da liberdade de atuação negocial do cidadãocontribuinte e do poder de tributar do Estado-Fisco tem gerado, há muito, uma intensa discussão doutrinária e jurisprudencial. Em suma, a questão é saber até que ponto a atuação do contribuinte no âmbito das relações privadas pode evitar a pretensão estatal de incidência de normas tributárias, ou seja, o âmbito de liberdade para o planejamento tributário: tem-se apontado como classificação das possibilidades decorrentes desse cálculo normativo-fáctico a existência de "elisão" e "evasão" tributárias ${ }^{1}$, de conteúdos semanticamente mais claros, e o pantanoso terreno da chamada "elisão abusiva", ou "elusão", dentre outros términos, comumente utilizados pelo meio jurídico nacional e internacional.

Tem-se, por certo, no campo do planejamento tributário, que a elisão tributária ${ }^{2}$ é uma atuação lícita do contribuinte, enquanto sua antípoda, a evasão tributária ${ }^{3}$, por sua vez, é uma

\footnotetext{
${ }^{1}$ Comumente se utiliza na doutrina e jurisprudência o adjetivo "fiscal" para qualificar a evasão e a elisão. Preferimos, todavia, a voz "tributária", para evitar a conotação ligada ao Direito Financeiro.

2 Também denominada "economia tributária”, "evasão", “evasão legal”, "evasão lícita", "evasão em sentido estrito" e "elusão". (QUEIROZ, 2005, p. 712)

${ }^{3}$ Também chamada de "fraude fiscal” e "evasão ilícita". (QUEIROZ, 2005, p. 713)
} 
atuação ilícita. Esses são os pontos mais límpidos, iluminados, do fenômeno jurídico sob estudo. Apesar da aparente claridade dos conceitos, há divergência na distinção entre ambos, como, aliás, aduz Luís Cesar Souza de Queiroz:

Sobre esse ponto o dissenso doutrinário é maior que o atinente à nomenclatura utilizada. Em que pese a elevada divergência, há um certo consenso quanto à presença de um critério comum entre os fenômenos da evasão e da elisão e quanto à existência de outro critério que fortemente os distingue. (QUEIROZ, 2005, p. 713)

É comum encontrar na doutrina nacional a distinção entre elisão e evasão calcada num aspecto meramente cronológico, o que, segundo Sergio Luís Petrasso Corrêa, é problemático. A diferença seria, por essa linha, que, na elisão, os atos praticados visando a menor oneração tributária do contribuinte se dariam antes da ocorrência do respectivo fato gerador; já na evasão, depois. (CORRÊA, 2011, p. 416-417). Mas, como recorda André Mendes Moreira:

[....] há hipóteses nas quais a evasão físcal antecede a efetiva incidência da norma tributária. $\mathrm{O}$ caso clássico do comerciante que emite notas fiscais adulteradas e somente após promove a saída da mercadoria de seu estabelecimento é típico exemplo das falhas existentes ao empregar-se somente o critério temporal para diferenciação dos institutos. (MOREIRA, 2003, p. 13).

Aproximando as figuras tem-se o fato de que, em ambas, o contribuinte age na busca do menor custo tributário possível; na elisão, contudo, o fim é alcançado de modo lícito, mediante autorização implícita do ordenamento jurídico, enquanto na evasão, o procedimento adotado é vedado, sendo considerado ilícito. (QUEIROZ, 2005, p. 713-714). Na elisão tributária, como afirma Regina Helena Costa, tem-se a noção de planejamento tributário:

De fato, doutrina e jurisprudência, há muito, admitem a elisão físcal. A expressão elisão fiscal é preferencialmente utilizada para denominar procedimentos legítimos, permitidos ao contribuinte, no intuito de fazer reduzir o ônus tributário, ou, ainda, significando a possibilidade de diferimento de obrigações fiscais. Visa, assim, a economia fiscal, mediante a utilização de alternativas lícitas, menos onerosa ao contribuinte, afinando-se à ideia de planejamento tributário. (COSTA, 2013, p. 202; COSTA., 2007, p. 290).

Pode-se apontar, também, que a elisão precede "a ocorrência do fato gerador no mundo fenomênico", enquanto que a sonegação e a fraude "dão-se após a ocorrência daquele fato". (TORRES, 2009, p. 246). A evasão tributária, assim, "fixa-se no campo da ilicitude", como recorda Sacha Calmon Navarro Coêlho, sendo suas modalidades, segundo o referido autor: 
a) o dolo (sonegação omissiva);

b) a fraude material (falsificação de documentos em geral);

c) a simulação absoluta ou relativa (mediante o abuso de formas de Direito Privado, eis que "abuso de formas $=$ dissimulação relativa $=$ fraude à lei fiscal") $(\mathrm{COÊLHO}$, 2003, p. 193)

Há, ainda, a chamada elisão imprópria, que são as previsões explícitas do ordenamento jurídico de autorização para procedimentos "que podem ser usados com o propósito de incorrer numa menor carga tributária", situação em que se enquadram os chamados "favores" ou “benefícios fiscais". (QUEIROZ, 2004, p. 712).

Contudo, não se deve olvidado uma parcela de situações que se encontram na penumbra conceptual: seria o caso da atuação lícita do contribuinte, no âmbito privado, a ser desconsiderada para fins tributários, posto ser abusiva. Eis a chamada elisão abusiva, ou alusão tributária, que decorreria de um abuso de formas do particular no intuito de evitar a incidência da norma tributária.

Marco Aurélio Greco identifica na modificação do contexto sociojurídico atual o advento da relevância dessa distinção. O autor considera que depois do que denomina de uma primeira fase de "Liberdade salvo Simulação" e de uma segunda fase de "Liberdade salvo patologias", chegou-se a uma terceira fase, de "Liberdade com Capacidade Contributiva", em que a liberdade perde o predomínio para se equilibrar com o valor solidariedade social, ganhando relevância o tema da capacidade contributiva. (GRECO, 2006, p. 264-271).

Afinal, para o autor, a "[c]apacidade contributiva é conceito não formal que se vincula, também, à ideia de rateio do custeio do funcionamento do Estado (um dever fundamental) e à isonomia de tratamento perante esse dever.” (GRECO, 2006, p. 272).

Ricardo Lobo Torres recorda, nesse diapasão, que a elisão é considerada lícita pelos defensores da interpretação lógico-sistemática e do primado dos conceitos do direito civil, sendo de se notar a posição de Sampaio Dória. O posicionamento da ilicitude da elisão, em declínio, era defendido pelos "adeptos da consideração econômica ${ }^{4}$ do fato gerador e da autonomia do direito tributário, já que constituiria abuso de forma jurídica qualquer descoincidência entre a roupagem exterior do negócio e o conteúdo econômico que lhe corresponde", dentre os quais cita Amilcar de Araújo Falcão. Conclui o autor no sentido de que algumas visões teóricas contemporâneas, como a jurisprudência dos valores e o pós-positivismo aceitam a licitude do planejamento tributário, desde que sem o abuso de direito, classificada

\footnotetext{
${ }^{4}$ Um bom resumo do histórico da interpretação econômica no Direito Tributário encontra-se na obra de Luís Eduardo Schoueri (SCHOUERI, 2011, p. 613-635).
} 
como elisão abusiva ou planejamento inconsistente, como é o caso de Klaus Tipke. (TORRES, 2009, p. 246-247).

De tudo isso, como bem apontou Eurico Marcos Diniz de Santi, denota-se que:

\begin{abstract}
Na última década, assistimos ao combate ideológico e teórico de duas concepções sobre o planejamento tributário, representadas por renomados juristas: de um lado, a defesa do Estado Liberal, dos princípios da livre iniciativa, da ampla liberdade negocial e da tipicidade cerrada o fato gerador; de outro, a defesa do Estado Social, a busca da solidariedade e da capacidade contributiva como valores constitucionais, pretendendo oferecer alternativas à "teoria do fato gerador" e propondo a re-qualificação do fato em sintonia com o verdadeiro propósito negocial. Ideologias não se comunicam nem se conciliam: são crenças, questões de fé e só por isso merecem respeito. Também a opção por determinados princípios revela convicções conceptuais impassíveis de serem derrotadas umas pelas outras. (SANTI, 2009, p. 310-311)
\end{abstract}

Seria possível a desconsideração dos atos e negócios privados para fins de aplicação da norma de incidência tributária? Vale dizer: existe realmente espaço em nosso ordenamento jurídico para a chamada elisão abusiva, ou, emprestando a expressão utilizada pelo mesmo Eurico Marcos Diniz de Santi, trata-se tal instituto de uma "ilusão"? (SANTI, 2006, p. 223224).

Não se pode negar que, apesar de vozes contrárias, há um certo consenso de que existe algo que se coloca entre a elisão e a evasão tributárias, algo que "irrita" o sistema tributário, quedado num limbo, entre o lícito e o ilícito. Sua natureza e seus limites, contudo, são algo a construir.

\title{
3 LEGALIDADE, LIBERDADE E O ABUSO DE FORMAS NO DIREITO TRIBUTÁRIO
}

O rigor do Princípio da Legalidade Tributária em nosso ordenamento jurídico produz relevantes consequências em relação aos limites da atuação fiscal. Afinal, o teor do artigo 150, inciso I, de nossa Constituição, como reforço das previsões do "caput" de seu artigo 37 e do próprio inciso II, de seu artigo $5^{\circ}$, levaram ao entendimento de que a rigidez da legalidade autorizaria a se falar de "estrita legalidade", quiçá de "tipicidade tributária", muito próxima à noção análoga aplicável na seara do Direito Penal. (CUNHA, 2011, p. 134-139). Com efeito, a aplicação das normas de incidência tributária exige a verificação da estrita subsunção do fato à 
previsão normativa, que deve arrolar todos os elementos a que se refere o artigo 97 do Código Tributário Nacional - $\mathrm{CTN}^{5}$.

Daí decorre que a aplicação de presunções e ficções no âmbito tributário deve ser analisada com mão avara, como recorda Roque Antônio Carrazza. (CARRAZZA, 2004, p. 245). A própria noção de legalidade traz inserta uma contraparte: o desenho da liberdade de atuação do particular. Afinal, se o cidadão apenas é obrigado a fazer ou deixar de fazer alguma coisa havendo previsão legal, como aduz o artigo $5^{\circ}$, II, da $\mathrm{CF} / 88$, e à Administração Pública compete a estrita observância das previsões legais, nos termos do artigo 37 e do art. 150, I, também da Carta Magna, sabe-se, de antemão, que existe um espaço livre à atuação do contribuinte em seus negócios, uma proteção ao livre-arbítrio dentro da moldura da licitude.

Já Kelsen aduzia que, por mais totalitária que fosse a ordem jurídica, sempre restaria um mínimo de liberdade ao ser humano (KELSEN, 2003, p. 48). Dito isso, com muita mais razão, num ordenamento jurídico democrático, como o brasileiro, não há dúvidas de que a margem de atuação lícita dos cidadãos é considerável.

A própria Constituição Federal acaba por expressar positivamente alguns aspectos dessa liberdade do particular em vários dispositivos. Dentre os que trazem reflexos no âmbito tributário, convém recordar a garantia de liberdade de trabalho (art. $5^{\circ}, \mathrm{XIII}, \mathrm{CF} / 88$ ), a livre iniciativa (art. 170, CF/88) e a garantia do direito de propriedade (art. $5^{\circ}, \mathrm{XXII}, \mathrm{CF} / 88$ ).

De se notar, no mais, que o simples fato de o contribuinte escolher um determinado procedimento, ao invés de outro, tendo em vista a menor carga tributária como fator determinante, não é algo ilícito, havendo hipóteses em que tal escolha é, inclusive, uma obrigação jurídica, sob pena de responsabilidade do agente, como sói ocorrer no caso da administração de uma pessoa jurídica com fins lucrativos, observados os limites da legalidade.

\footnotetext{
5 “Art. 97. Somente a lei pode estabelecer:

I - a instituição de tributos, ou a sua extinção;

II - a majoração de tributos, ou sua redução, ressalvado o disposto nos artigos 21, 26, 39, 57 e 65;

III - a definição do fato gerador da obrigação tributária principal, ressalvado o disposto no inciso I do $\S 3^{\circ}$ do artigo 52, e do seu sujeito passivo;

IV - a fixação de alíquota do tributo e da sua base de cálculo, ressalvado o disposto nos artigos 21, 26, 39, 57 e 65 ;

V - a cominação de penalidades para as ações ou omissões contrárias a seus dispositivos, ou para outras infrações nela definidas;

VI - as hipóteses de exclusão, suspensão e extinção de créditos tributários, ou de dispensa ou redução de penalidades.

$\S 1^{\circ}$ Equipara-se à majoração do tributo a modificação da sua base de cálculo, que importe em torná-lo mais oneroso.

$\S 2^{\circ}$ Não constitui majoração de tributo, para os fins do disposto no inciso II deste artigo, a atualização do valor monetário da respectiva base de cálculo."
} 
(QUEIROZ, 2005, p. 714). Casos de autorização explícita do ordenamento jurídico existem, como a de escolha do local de instalação de um empreendimento em face de vantagens tributárias, a escolha pela sistemática do lucro presumido no âmbito do Imposto sobre a Renda da Pessoa Jurídica - IRPJ, ou da escolha de modalidade simplificada de declaração no Imposto sobre a Renda da Pessoa Física - IRPF (QUEIROZ, 2005, p. 715). Aliás, como aduz Navarro Coêlho, "Ao cabo, economizar licitamente tributos é, por si só, um propósito negocial (minimização de custos)." (COÊLHO, 2003, p. 195).

A liberdade que nosso sistema jurídico outorga ao contribuinte, contudo, é irrestrita? Obviamente que não. O próprio ordenamento jurídico cuida de limitar as franjas dessa liberdade individual, inclusive com efeitos tributários. O próprio fato da tributação é, "per se", uma limitação à liberdade individual, fonte de eternas tensões sistêmicas, ao atingir a garantia da propriedade privada e da liberdade de atuação do particular. Há, no entanto, situações ainda mais extremas, como, exemplificativamente, a progressividade-sanção sobre a propriedade que não cumpre sua função social, seja na tributação de imóveis urbanos (artigo 182, § 4 , II, $\mathrm{CF} / 88$ ), seja na de imóveis rurais (art. 153, § $4^{\circ}, \mathrm{I}, \mathrm{CF} / 88$ ). Um outro exemplo, decorrente da aplicação da proteção à livre concorrência, é o precedente do Supremo Tribunal Federal - STF no julgamento do RE 550.769-RJ ${ }^{6}$.

Há limites, portanto, ao planejamento tributário do contribuinte, visando à diminuição do ônus econômico no pagamento de tributos? Sim, há. Claramente, existe o campo da ilicitude, já mencionado, classificado como evasão tributária, pelo qual não pode o particular caminhar, segundo as previsões de nosso ordenamento jurídico.

\footnotetext{
${ }^{6}$ EMENTA: CONSTITUCIONAL. TRIBUTÁRIO. SANÇÃO POLÍTICA. NÃO-PAGAMENTO DE TRIBUTO. INDÚSTRIA DO CIGARRO. REGISTRO ESPECIAL DE FUNCIONAMENTO. CASSAÇÃO. DECRETO-LEI 1.593/1977, ART. $2^{\circ}$, II. 1. Recurso extraordinário interposto de acórdão prolatado pelo Tribunal Regional Federal da $2^{\text {a }}$ Região, que reputou constitucional a exigência de rigorosa regularidade fiscal para manutenção do registro especial para fabricação e comercialização de cigarros (DL 1.593/1977, art. $2^{\circ}$, II). 2. Alegada contrariedade à proibição de sanções políticas em matéria tributária, entendidas como qualquer restrição ao direito fundamental de exercício de atividade econômica ou profissional lícita. Violação do art. 170 da Constituição, bem como dos princípios da proporcionalidade e da razoabilidade. 3. A orientação firmada pelo Supremo Tribunal Federal rechaça a aplicação de sanção política em matéria tributária. Contudo, para se caracterizar como sanção política, a norma extraída da interpretação do art. $2^{\circ}$, II, do Decreto-lei 1.593/1977 deve atentar contra os seguintes parâmetros: (1) relevância do valor dos créditos tributários em aberto, cujo não pagamento implica a restrição ao funcionamento da empresa; (2) manutenção proporcional e razoável do devido processo legal de controle do ato de aplicação da penalidade; e (3) manutenção proporcional e razoável do devido processo legal de controle da validade dos créditos tributários cujo não-pagamento implica a cassação do registro especial. 4. Circunstâncias que não foram demonstradas no caso em exame. 5. Recurso extraordinário conhecido, mas ao qual se nega provimento.

(RE 550769, Relator(a): Min. JOAQUIM BARBOSA, Tribunal Pleno, julgado em 22/05/2013, ACÓRDÃO ELETRÔNICO DJe-066 DIVULG 02-04-2014 PUBLIC 03-04-2014)
} 
Ademais, como também já exposto, existe o campo da licitude, afeto à ideia de elisão tributária, mediante a qual, através de escolhas negociais lícitas, pode o contribuinte deixar de recolher ou recolher montante menor de tributos. E não se pode negar ser legítimo ao particular a busca plena dessa desoneração lícita no âmbito exacional: tal liberdade decorre, com efeito, de premissas básicas de nossos sistemas jurídico e econômico. Havendo a possibilidade de atuação que gere menor impacto fiscal, não haveria de se falar em obrigação de o contribuinte eleger o caminho mais oneroso. Isso contrariaria a noção mínima de liberdade de que falamos antes, além de afrontar a ideia de eficiência econômica, que é basilar num sistema capitalista.

A questão que se mantém em aberto é, portanto, sobre a existência de limites a uma atuação lícita, mas, supostamente, abusiva, do particular, em que se encaixa o conceito de elisão abusiva. É nesse campo pantanoso em que se encontram temas como o "abuso das formas", a busca pelo "propósito negocial" etc.

Em nosso direito, regras recentes sobre a abusividade de formas, e a análise científica de seus efeitos no Direito Tributário, não podem ser desconsideradas, com o atual Código Civil prevendo, expressamente, o abuso de direito como ato ilícito, definindo-o em seu art. 187:

Art. 187. Também comete ato ilícito o titular de um direito que, ao exercê-lo, excede manifestamente os limites impostos pelo seu fim econômico ou social, pela boa-fé ou pelos bons costumes.

Isso não é inédito no ordenamento jurídico brasileiro, como se denota, por exemplo, do art. $5^{\circ}$ da Lei de Introdução às Normas do Direito Brasileiro, o qual determina ao juiz o atendimento aos fins sociais a que se dirige a lei, em sua aplicação, e às exigências do bem comum. Afinal, "a ilicitude do ato abusivo se caracteriza sempre que o titular do direito se desvia da finalidade social para a qual o direito subjetivo foi concedido.” (GONÇALVES, 2012, p. 394). Desse modo, a legislação civil prevê que, ainda quando atuando dentro do âmbito de suas prerrogativas, uma pessoa possa ser responsabilizada à indenizar os danos causados, se tiver de sua atuação feito um uso abusivo, o que seria, por igual razão, aplicável ao Direito Tributário, fundando-se no princípio da relativização dos direitos subjetivos. (CORRÊA, 2011, p. 418).

Ademais, a legislação civil trata dos conceitos e efeitos da simulação há muito. Ora, a simulação "é uma declaração falsa da vontade, visando aparentar negócio diverso do efetivamente desejado", "é o que tem aparência contrária à realidade", em que há conluio entre os contratantes, para se "obter efeito diverso daquele que o negócio aparenta conferir." 
(GONÇALVES, 2012, p. 366). Nessa linha, difere do dolo, "porque neste a vítima participa da avença, sendo, porém, induzida em erro", inexistindo vítima na simulação, que visa a iludir terceiros ou violar a lei (GONÇALVES, 2012, p. 366); havendo dela espécies: a) na absoluta, não existe negócio e as partes apenas fingem sua existência, uma "ilusão externa"; e b) na relativa, as partes dão ao negócio aparência diversa da real e existem dois negócios: o simulado, que é aparente, visando a iludir; e o dissimulado, que está oculto, mas que é o verdadeiramente desejado. (GONÇALVES, 2012, p. 367). Daí a diferença entre a simulação e a dissimulação.

Como recorda Luís César Souza de Queiroz:

Pode-se afirmar que os negócios praticados com simulação (absoluta ou relativa) ou fraude à lei, e que causam prejuízos a terceiros, inclusive à Fazenda Pública, têm sido pacificamente considerados como procedimentos ilícitos, típicos de evasão tributária. Alguns incluem também o dolo como causa para caracterizar a ilicitude do procedimento. [...] Em matéria tributária, aquilo que alguns chamam de dolo e que identificam como elemento caracterizados do ilícito e, por conseguinte, da evasão tributária, é normalmente o que os estudiosos do Direito Civil identificam como simulação ou fraude à lei. (QUEIROZ, 2005, p. 716-717).

E referido autor arrola os novos casos que o Código Civil prevê para a nulidade do negócio jurídico:

a) quando o motivo determinante, comum a ambas as partes, for ilícito (art. 106, III);

b) quando tiver por objetivo fraudar lei imperativa (art. 166, VI);

c) quando a lei taxativamente o declarar nulo, ou proibir-lhe a prática sem cominar sanção (art. 166, VII); e

d) houver simulação, subsistindo, contudo, o negócio dissimulado, se este for válido na substância e na forma (art. 167, caput). (QUEIROZ, 2005, p. 717).

Para Luciano Amaro, o questionamento sobre o abuso de forma, ou abuso de direito e simulação, seria atitude interpretativa menos radical se comparada à exegese econômica em sua formulação mais rigorosa. Tratar-se-ia da definição de forma de interpretação da legislação, diante de determinados comportamentos do contribuinte, o qual, "em geral de modo voluntário, procura estruturar seus negócios e suas atividades seguindo caminhos que se revelam fiscalmente menos onerosos." (AMARO, 2009, p. 229).

Ensina referido autor que o abuso de forma seria a utilização pelo contribuinte de uma forma jurídica atípica, anormal ou desnecessária, na realização de um negócio jurídico que, em contraposição a uma forma "normal", seria menos onerosa tributariamente falando. Confundindo-se em certa medida com o abuso de forma, ter-se-ia o abuso de direito, em que os procedimentos adotados, previstos legalmente, "só estariam sendo concretamente adotados para 
fins outros que não aqueles que normalmente decorreriam de sua prática." (AMARO, 2009, p. 231). A simulação, por sua vez, ocorreria na falta de correspondência entre o negócio realmente praticado e o formalizado. O autor conclui que a teoria do abuso de forma "deixa ao arbítrio do aplicador da lei a decisão sobre a 'normalidade' da forma utilizada", ressaltando que o foco não é a legalidade da forma, mas sua "normalidade", ferindo o postulado da segurança jurídica e da certeza do direito (AMARO, 2009, p. 231). Assim, para ele, "se a forma utilizada pelo contribuinte for lícita (vale dizer, prevista ou não defesa em lei), ela não pode ser considerada abusiva, o que traduziria uma contradição." (AMARO, 2009, p. 231). Situação diversa levaria ao absurdo de se concluir que "o contribuinte seria sempre obrigado a escolher o caminho de maior onerosidade fiscal." (AMARO, 2009, p. 233).

Queiroz também aponta alguns critérios que não são aceitos de modo pacífico pela doutrina, a fim de distinguir os casos de evasão dos de elisão:

a) a teoria da interpretação econômica, adotada por AMÍLCAR DE ARAÚJO FALCÃO e severamente criticada por ALFREDO AUGUSTO BECKER;

b) a teoria do abuso da forma jurídica, adotada na Alemanha, mas que, por implicar utilização de analogia, seria vedada em nosso ordenamento jurídico;

c) as teorias antielisivas nos Estados Unidos, que inclui, como exemplos, a teoria do propósito negocial ou empresarial (the business purpose doctrine) e a teoria da substância sobre a forma (the business over form doctrine). (QUEIROZ, 2005, p. 722728).

O tema da desconsideração de negócios para fins tributários com base em conceitos como a existência de efetivo propósito negocial nasceu e frutificou fortemente no direito alienígena. Não se pode olvidar do que Alberto Xavier escreveu, em carta, a Navarro Coêlho, quando estava indignado com a edição da Medida Provisória n. 66/2002, que visava a regulamentar o parágrafo único do art. 116 do CTN:

[...] do ponto de vista político, que a doutrina da cláusula geral antielisiva ou do abuso de forma foi inspirada e mereceu o aplauso das ditaduras nazi-fascistas. [...]

Que resta da liberdade civil de contratação, da liberdade econômica de organização e da propriedade dos bens legitimamente adquiridos? E em mãos de quem fica esse poder de pesquisar, devassar, investigar e apreciar as razões que levam o cidadão a seguir um caminho em vez de outro?

O clima de terror fiscal que um sistema dessa natureza inevitavelmente introduz é incompatível com a segurança jurídica, essencial ao Estado-de-Direito e à economia de mercado, pois sem ela é impossível a expressão da livre iniciativa, que requer segurança e liberdade, sem os quais não há propriedade nem planejamento empresarial possível. [...] (XAVIER APUD COÊLHO, 2003, p. 180-181). 
Schoueri cita como limites à consideração econômica no Direito Tributário alienígena as situações para as quais o legislador efetivamente "se fixou em uma categoria de Direito Privado", entendendo-se que "ela não é suficiente para coibir a prática de planejamento tributário quando o contribuinte afasta a ocorrência daquela circunstância civil, mesmo que exclusivamente para evitar a tributação”. (SCHOUERI, 2011, p. 630). E afirma, criticamente, que "a consideração econômica e o abuso de formas jurídicas recaíram, indevidamente, em métodos jurídico-sociológicos que levam a uma avaliação econômica da situação fática", podendo chegar a resultados próximos ao da Escola Livre do Direito, cheios de perigos. (SCHOUERI, 2011, p. 631).

De se notar que a teoria da substância sobre a forma nasceu nos EUA, no início do século XX, em precedentes da Suprema Corte daquela país, e possui a natureza de modo de interpretação da lei tributária, "um modo de se combater a elisão tributária", sendo adotada, em alguns casos, em favor do contribuinte. (MCNAUGHTON, 2014, p. 16-18).

Para Luís César Souza de Queiroz, as peculiaridades do sistema constitucional brasileiro, em face dos sistemas americano e alemão, em especial o Princípio da Repartição Constitucional da Competência Tributária e o Princípio da Estrita Legalidade Tributária, “implica uma impossibilidade lógico-jurídica para a adoção de qualquer uma daquelas teorias estrangeiras antielisivas antes examinadas, pois tais teorias acabam implicando a adoção da analogia para que ocorra a exigência de um tributo.” (QUEIROZ, 2005, p. 728-729). Afinal, a tributação analógica tornaria sem efeito a rígida repartição constitucional de competências em que se demora a Constituição de 1988, além do que a Legalidade Tributária torna defeso a utilização da analogia em nosso sistema. (QUEIROZ, 2005, p. 733-735).

Como afirma Charles William Mcnaughton, a aplicação da requalificação dos negócios jurídicos não é mera relativização da legalidade, é o "avesso à legalidade: a manipulação dos critérios da norma tributária, por autoridade fiscal", uma "tributação casuística". (MACNAUGHTON, 2014, p. 30). Afinal:

[...] se a norma antielisiva genérica burla a legalidade, a norma antielisiva genérica "colorida" pela necessidade de propósito negocial pode acarretar também situações em que se viola a isonomia, porque contribuintes que têm a "boa fortuna" de apresentar uma razão extratributária convincente podem ter seu planejamento acatado em detrimento de outros que não tiveram essa "sorte". (MACNAUGHTON, 2014, p. 30)

Como visto, há uma verdadeira "Babel" doutrinária na classificação das figuras localizadas na zona de penumbra entre a evasão e a elisão tributárias. Se, de um lado, podemos 
verificar figuras claramente ilícitas, incluídas no conceito de "evasão tributária", como a simulação e a dissimulação nos negócios privados, há situações controversas, de pouco ou nenhum consenso, como a necessidade de verificação do "propósito negocial", tão em voga na jurisprudência administrativa atual.

Diante de tal quadro, ficamos com Amaro ao considerar legítimo o planejamento tributário:

É legítima a eleição propositada de formas jurídicas (lícitas, obviamente) que resultem ou possam resultar em menor incidência tributária. [...]

Noutras palavras, não configura prática ilegítima aquilo que se costuma denominar planejamento tributário. $(2009$, p. 235).

Até porque, como recorda Santi (2009, p. 321):

Reitere-se: a falta de critérios normativos dá espaço para o exercício da arbitrariedade embasada num maniqueísmo fiscal em que já não importa mais o fato gerador previsto em lei; importa, sim, a intenção de realizar o ato de incorporação ou a subscrição de capital com ágio, aferida mediante a inexistência de "propósito negocial" (business purpose), isto é, a ausência de outros motivos (econômicos, comerciais, societários) - ou outras intenções - para a realização da reorganização societária.

Fato é que não nos parece possível, em nosso ordenamento jurídico, a instituição de um “imposto sobre planejamento tributário", cuja hipótese de incidência seria "pagar menos tributo com a intenção de pagar menos tributo em conformidade com a lei”, como muito bem apontou Eurico Marcos Diniz de Santi (SANTI, 2009, p. 314).

\section{A LEI COMPLEMENTAR 104/2001 E O PARÁGRAFO ÚNICO DO ART. 116, DO CTN}

Decorrência da tentativa de aplicação de conceitos de desconsideração de negócios jurídicos para fins tributários próprios de outros sistemas jurídicos, o legislador complementar nacional incluiu o parágrafo único ao art. 116, do CTN, que reza:

Art. 116. [...] Parágrafo único. A autoridade administrativa poderá desconsiderar atos ou negócios jurídicos praticados com a finalidade de dissimular a ocorrência do fato gerador do tributo ou a natureza dos elementos constitutivos da obrigação tributária, observados os procedimentos a serem estabelecidos em lei ordinária. 
A natureza, validade e a eficácia desse dispositivo ainda se encontra em discussão em nossa doutrina, passados quatorze anos da promulgação da Lei Complementar n. 104/2001, que o incluiu no CTN.

Quanto à sua natureza, há quem afirme que este dispositivo funciona como uma cláusula geral antielisão, permitindo ao Fisco a ampla desconsideração dos negócios privados. Outros o veem apenas como uma reiteração expressa de algo já então existente em nosso ordenamento: o impedimento da simulação, típica cláusula antievasiva. A visão sobre a validade da modificação normativa promovida pela LC 104/2001 também difere consideravelmente.

Regina Helena Costa considera imprópria a expressão "norma geral antielisiva", uma vez que somente visaria a impedir "práticas ilícita destinadas justamente a evitar a configuração da obrigação tributária", pelo que seria melhor "falar-se em norma geral 'antievasiva' ou 'antissimulação'." (COSTA, 2013, p. 202; COSTA, 2007, p. 290). O foco de referida norma seria evitar a dissimulação de ato ou negócio jurídico (COSTA, 2013, p. 202; COSTA, 2007, p. 290).

Referida autora considera que o ordenamento jurídico pátrio já autorizava a desconsideração de negócios dissimulados, em face da previsão do art. 149, VII, do Código Tributário Nacional. Ela conclui no sentido de que a falta da regulamentação enseja ameaça à segurança jurídica, e que "seria necessário um rol de hipóteses" no dispositivo, em que pese os casos previstos no mencionado inciso VII do art. 149, do CTN sejam, segundo sua visão sobre o tema, praticamente as mesmas de aplicação do dispositivo. (COSTA, 2013, p. 203-204; COSTA, 2007, p. 294-296). Hoje, pela falta da regulamentação, ela seria exemplo de inadequada aplicação da praticabilidade tributária. (COSTA, 2013, p. 204-205; COSTA, 2007, p. 296).

Paulo de Barros Carvalho também entende que a desconsideração de dissimulações já se encontrava autorizada, com base no art. 149, VII, do CTN, sendo que o parágrafo único, do art. 116, apenas veio ratificar tal hipótese. (CARVALHO, 2007, p. 288). Referido autor, contudo, esclarece que a autorização legal não poderia abarcar negócio jurídico realizado em decorrência de planejamento tributário, cujos negócios válidos não se confundem com atos dissimulados, "consistentes na ilegal ocultação da ocorrência do fato jurídico tributário", não podendo referido dispositivo impedir o planejamento, uma vez que o contribuinte "é livre para escolher o ato que pretende praticar, acarretando, conforme sua escolha, o nascimento ou não de determinada obrigação tributária”. (CARVALHO, 2007, p. 289). Nessa mesma linha é o pensamento de Luís César Souza de Queiroz (2005, p. 739). 
Também no mesmo sentido vai Sacha Calmon Navarro Coêlho, que entende que o referido dispositivo não inovou em nosso ordenamento jurídico, apenas explicitando o que já era sabido, delegando "à lei a função de organizar os procedimentos de desconsideração dos atos e negócios dissimulados." (COÊLHO, 2003, p. 175)

Também partindo da premissa de que a previsão do Parágrafo Único, do art. 116, do CTN, apenas trata de uma norma antievasão, Luís César Souza de Queiroz afirma:

De certo modo, a previsão do Código Civil de 2002 sobre a possibilidade de preservação do negócio dissimulado se compatibiliza com o que dispõe o parágrafo único do art. 116 do Código Tributário Nacional, à medida que é conferido à autoridade tributária o poder de desconsiderar o ato ou negócio simulado e levar em conta, para fins tributários, o negócio dissimulado. (QUEIROZ, 2005, p. 720-721).

Também no que se refere à eficácia do dispositivo, vê-se desde defensores de sua autoaplicabilidade incondicional, até aqueles que consideram o dispositivo com restrita eficácia técnica, o que exigiria a edição de lei ordinária federal, para alguns, e de cada ente federativo, para outros.

$\mathrm{Na}$ esfera federal, essa lei não existe, ainda. Verdade que tramitaram, ao menos, duas tentativas: (i) a Medida Provisória de n. 66/2012, que em seu artigo 13 e seguintes procurava regulamentar a "norma geral antielisão", trecho rejeitado pelo Parlamento em 2002; e (ii) a Medida Provisória de n. 685/2015, que criava a obrigação de declaração de operações envolvendo atos ou negócios jurídicos que acarretassem supressão, redução ou diferimento de tributo (art. $7^{\circ}$ e seguintes), esta última rejeitada recentemente, no particular, pelo Congresso Nacional.

Há exemplos esparsos, contudo, país afora, como a lei paulistana n. 14.133/2006, que prevê a autorização para os auditores físcais desconsiderarem negócios jurídicos levando em consideração conceitos positivados de "falta de propósito negocial" - definida pela lei como a "opção pela forma mais complexa ou onerosa, para os envolvidos, entre duas ou mais formas para a prática de determinado" - ou "abuso de forma" - definida como "a prática de ato ou negócio jurídico indireto que produza o mesmo resultado econômico do ato ou negócio jurídico simulado". (GONÇALVES, 2011, p. 83; CORRÊA, 2011, p. 420).

\footnotetext{
${ }^{7}$ De se notar que referido autor identifica a ideia de dissimulação ao abuso de formas de direito privado, utilizados para ocultar um negócio real tributado ou menor tributado que o negócio aparente. (COÊLHO, 2003, p. 177).
} 
E mesmo se a referida lei vier a ser promulgada, consideramos fortes os apontamentos feitos por Sacha Calmon Navarro Coêlho, sobre os requisitos que ela deverá observar:

A elisão está no campo da licitude. Pois bem, a norma específica antielisiva tem de ser, para ter legitimidade: a) razoável; b) proporcional; c) prévia; d) não-punitiva; e) legislada; f) dizer expressamente que regime jurídico tributário deve-se aplicar ao negócio elidido, caso a caso. E, mais, se usar presunções, estas serão sempre relativas par suportar a prova em contrário. Nestes termos será legítima, preservando-se a legalidade, a segurança e a certeza do direito. A regra geral antielisiva não é regra, a rigor, de interpretação, nem antielisiva, mas de competência, [...] para que o aplicador ex officio da lei, dela se afaste, podendo a posteriori escolher segundo os vagos critérios do business purpose e do abuso de forma jurídica, da "fraude à lei fiscal", que regime tributário deve ser utilizado para o negócio jurídico já praticado, ferindo profundamente a legalidade, a liberdade, a segurança e a certeza do direito. [...] (COÊLHO, 2003, p. 184).

De qualquer modo, acompanhamos o entendimento da doutrina aqui mencionada, no sentido de que a previsão do controverso parágrafo único do art. 116 do CTN não possui a natureza de uma "norma geral antielisão", mas, tão somente, de permissão à autoridade fazendária para desconsiderar os negócios jurídicos simulados e/ou dissimulados, tendo natureza, portanto, de cláusula geral antievasão tributária.

\section{CONCLUSÃO}

Por meio do presente estudo analisou-se, brevemente, a celeuma doutrinária acerca das controversas figuras da elisão e evasão tributárias, assim como da zona cinzenta da chamada elisão abusiva.

Verificamos que não há liberdade irrestrita ao contribuinte em relação ao planejamento tributário, existindo o campo da ilicitude, classificado como evasão tributária; o campo da licitude, identificado como elisão tributária, ficando em aberta a questão de limites a uma atuação lícita, mas abusiva, do particular, em que se encaixa o conceito de elisão abusiva, em que discute o chamado "abuso das formas", o "propósito negocial" etc. Trata-se de uma zona de penumbra entre a evasão e a elisão tributárias.

Após tal análise, concluiu-se que a previsão do parágrafo único do art. 116 do CTN não possui a natureza de uma "norma geral antielisão", mas, tão somente, de permissão à autoridade fazendária para desconsiderar os negócios jurídicos simulados e/ou dissimulados, tendo natureza, portanto, de cláusula geral antievasão tributária. 


\section{REFERÊNCIAS}

AMARO, Luciano. Direito Tributário Brasileiro. 15 ed., São Paulo: Saraiva, 2009.

CARRAZZA, Roque Antônio. Curso de Direito Constitucional Tributário. 20 ed. São Paulo: Malheiros, 2004.

CARVALHO, Paulo de Barros. Curso de Direito Tributário. 18 ed. São Paulo: Saraiva, 2007.

COSTA, Regina Helena. Curso de Direito Tributário. São Paulo: Saraiva, 2013.

COSTA, Regina Helena. Praticabilidade e Justiça Tributária: Exeqüibilidade de lei Tributária e Direitos do Contribuinte. São Paulo: Malheiros, 2007.

COÊLHO, Sacha Calmon Navarro. Teoria Geral do Tributo, da Interpretação e da Exoneração Tributária: O significado do art. 116, parágrafo único, do CTN. $3^{\mathrm{a}}$ ed. São Paulo: Dialética, 2003.

CORRÊA, Sérgio Luís Petrasso. Planejamento Tributário: Evasão e Elisão Fiscal. In: PINTO, Sergio Luiz de Moraes; MACEDO, Alberto; ARAÚJO, Wilson José (coord.). Gestão Tributária Municipal e Tributos Municipais. São Paulo: Quartier Latin, 2011, p. 413-426.

CUNHA, Carlos Renato. O Simples Nacional, a Norma Tributária e o Princípio Federativo: Limites da Praticabilidade Tributária. Curitiba: Juruá, 2011.

GONÇALVES, Alexandre Tadeu Navarro Pereira. Autuações por Desconsideração dos Atos e Negócios Jurídicos por Falta de Propósito Negocial ou Abuso da Forma - Enfoque em Casos de ITBI-IV. In: PINTO, Sergio Luiz de Moraes; MACEDO, Alberto; ARAÚJO, Wilson José (coord.). Gestão Tributária Municipal e Tributos Municipais. São Paulo: Quartier Latin, 2011, p. 81-96.

GONÇALVES, Carlos Roberto. Direito Civil Esquematizado. V. 1. 2 ed. São Paulo: Saraiva, 2012.

GRECO, Marco Aurélio. Planejamento Tributário. In: SANTI, Eurico Marcos Diniz de; ZILVETI, Fernando Aurélio; MOSQUERA, Roberto Quiroga (coord.). Tributação das Empresas. São Paulo: Quartier Latin, 2006, p. 259-278.

KELSEN, Hans. Teoria Pura do Direito. Trad. João Baptista Machado. 6 ed. São Paulo: Martins Fontes, 2003.

MOREIRA, André Mendes. Elisão e Evasão Fiscal - Limites a Planejamento Tributário. Revista da Associação Brasileira de Direito Tributário, Vol. 21, Belo Horizonte, p. 11-17, mar.-abr. 2003. 
QUEIROZ, Luís César Souza de. Controle Normativo da Elisão Tributária. In: BARRETO, Aires Fernandino et al. II Congresso Nacional de Estudos Tributários: Segurança Jurídica na Tributação e Estado de Direito. São Paulo: Noeses, 2005, p. 711-750.

SANTI, Eurico Marcos Diniz de. Planejamento Tributário: Desafios Institucionais. In: MACEDO, Alberto et al. VI Congresso Nacional de Estudos Tributários: Sistema Tributário Brasileiro e a Crise Atual. São Paulo: Noeses, 2009, p. 309-326.

Planejamento Tributário e Estado de Direito: Fraude à Lei, reconstruindo conceitos. In: BARRETO, Ayres Fernandino e outros. III Congresso Nacional de Estudos Tributários: Interpretação e Estado de Direito. São Paulo: Noeses, 2006, p. 223-260.

SCHOUERI, Luís Eduardo. Direito Tributário. São Paulo: Saraiva, 2011.

TORRES, Ricardo Lobo. Curso de Direito Financeiro e Tributário. 16 ed. Rio de Janeiro: Renovar, 2009.

\section{DADOS DA PUBLICAÇÃO}

Categoria: artigo submetido ao double-blind review.

Recebido em: 25/07/2019.

Aceito em: 03/12/2020. 